Japanese Journal of Transfusion Medicine, Vol. 40. No. 5 40(5) : 730-736, 1994

症例

\title{
肺炎球菌敗血症に伴って発現した赤血球の $\mathrm{Th}$ 活性
}

\author{
秋林 建 ${ }^{1)}$ 近藤 誠司 ${ }^{1)}$ 大瀧 幸哉 ${ }^{1) 2)}$ \\ 宮崎医科大学医学部附属病院輸血部 ${ }^{12}$, 病態検查学講座 ${ }^{21}$
}

(平成 6 年 3 月 22 日受付)

\section{Th ACTIVATION OF RBC ASSOCIATED WITH PNEUMOCOCCEMIA}

\author{
Ken Akibayashi ${ }^{1}$, Seiji Kondoh ${ }^{1)}$ and Sachiya Ohtaki ${ }^{12)}$ \\ ${ }^{1)}$ Blood Transfusion Division, ${ }^{2)}$ Central Laboratory for Clinical Investigation, \\ Miyazaki Medical College
}

This report described (1) a case of Streptococcus pneumoniae bacteremia whose erythrocytes showed $\mathrm{Th}$ and $\mathrm{T}$ polyagglutination in different conditions, and (2) a further investigation indicating that Th transformation was the "prestage" of $\mathrm{T}$ activation caused by desialylation from red cell membrane with bacterial enzyme at least in the case of infection.

A screening test with Arachis hypogaea happened to find erythrocyte-polyagglutination in a sample from a 55-year-old man with pneumonia and septicemia of the bacteria. An immunohematological study demonstrated Th activation (Bird's classification) on the red cells obtained directly from the patient. This contrasted with $\mathrm{T}$ activation of the patient's red cells taken from a culture bottle.

Erythrocytes from a healthy donor revealed Th transformation, when incubated with the patient's serum at $37^{\circ} \mathrm{C}$ only for more than 5 hours, and $\mathrm{T}$ transformation, easily when incubated with the undiluted supernatant of the blood culture. Interestingly, 10 times dilution of the supernatant brought about Th activity on the red cells after 30 minutes incubation, followed by $\mathrm{T}$ activation after 60 minutes or more. The 100 times dilution induced solely $\mathrm{Th}$ phenomenon.

The experiments using bacterial $\mathrm{N}$-acetylneuraminic acid successfully transformed normal erythrocytes into either Th or $\mathrm{T}$ red cells, showing that the difference depended on the amount of sialic acid hydrolyzed: $4-21 \mu \mathrm{g} / 10^{10} \mathrm{RBC}$ for $\mathrm{Th}$ and $>21 \mu \mathrm{g} / 10^{10} \mathrm{RBC}$ for $\mathrm{T}$ transformation.

\section{はじめに}

Th polyagglutination は, 1978年に Bird らや Veneziano ら ${ }^{2)}$ にりそれぞれ細菌感染症患者か ら見いだされ, Arachis hypogaea (Peanut extract）レクチンと凝集を呈する第 3 型として報 告されている.

今回我々は, Arachis hypogaea レクチンによ るスクリーニングから肺炎・重度の呼吸不全で緊 急入院となった患者の赤血球に血清学的に Th 活 性を示す polyagglutinationの症例を経験した。 この患者の血液培養でStreptococcus pneumoniae が確認されたが, 血液培養ボトル中に含まれてい
た赤血球は $\mathrm{T}$ 活性を示していたことから，Th化 と $\mathrm{T}$ 化活性との関係について検討したので報告 する。

\section{症例}

患者：TT, 65歳, 男性.

主訴：咳, 喀痰, 右胸痛, 呼吸困難.

既往歴：昭和 62 年頃より，町立検診で肝機能障 害が指摘され開業医を受診し，C型慢性肝炎にて 通院加療されていた。

現病歴：平成 4 年 6 月 27 日夕方より悪寒と $38.2^{\circ} \mathrm{C}$ 台の発熱があったが放置していた。 6 月 29 日近医を受診し右肺野の異常陰影を指摘され，肺 
表 1 Laboratory results on admission

\begin{tabular}{lclr}
\hline $\mathrm{RBC}$ & $383 \times 10^{4} / \mu l$ & $\mathrm{TP}$ & $6.53 \mathrm{~g} / \mathrm{d} l$ \\
$\mathrm{Hb}$ & $13.0 \mathrm{~g} / \mathrm{d} l$ & $\mathrm{BUN}$ & $39.7 \mathrm{mg} / \mathrm{d} l$ \\
$\mathrm{Hct}$ & $40.6 \%$ & $\mathrm{Glu}$ & $26 \mathrm{mg} / \mathrm{d} l$ \\
$\mathrm{WBC}$ & $900 / \mu l$ & $\mathrm{Na}$ & $136 \mathrm{mEq} / l$ \\
$\mathrm{Plt}$ & $6.4 \times 10^{4} / \mu l$ & $\mathrm{~K}$ & $4.2 \mathrm{mEq} / l$ \\
& & $\mathrm{Cl}$ & $99 \mathrm{mEq} / l$ \\
$\mathrm{CRP}$ & $4+$ & T.Bil & $3.5 \mathrm{mg} / \mathrm{d} l$ \\
$\mathrm{pH}$ & 7.210 & $\mathrm{D} . \mathrm{Bil}$ & $2.4 \mathrm{mg} / \mathrm{d} l$ \\
$\mathrm{PO}_{2}$ & 38.5 & $\mathrm{GOT}$ & $75 \mathrm{IU} / l$ \\
$\mathrm{PCO}_{2}$ & 34.6 & $\mathrm{GPT}$ & $67 \mathrm{IU} / l$ \\
$\mathrm{HCO}_{3}{ }^{-}$ & 13.8 & $\mathrm{LDH}$ & $540 \mathrm{IU} / l$ \\
\hline
\end{tabular}

Blood culture

Streptococcus pneumoniae

炎及び重症呼吸不全の診断にて本院（第 2 内科） に緊急入院となる。

入院時現症：体重 $50 \mathrm{~kg}$, 体温 $36^{\circ} \mathrm{C}$, 血圧 $90 / 40$ $\mathrm{mmHg}$, 脈拍 $96 /$ 分, 起座呼吸 $(+)$, チアノーゼ $(+)$, 貧血 $(+)$, 黄疸 $(+)$, 右肺に湿性亏音を 聴取。

入院時検査所見 (表 1 ): 末梢血液検査では白血 球数と血小板数の減少を認めた. 血液生化学検査 では血清蛋白, 血糖が低下し, 一方血中尿素窒素, 総ビリルビン，直接型ビリルビンの増加が認めら れた。

入院後臨床経過：患者の検査所見や臨床所見か ら心, 肺, 腎, 肝などの多臓器不全と診断された。 また血液培養から Streptococcus pneumoniae が
同定され抗生物質が投与された。しかし患者は呼 吸不全により第 2 病日に死亡した。

\section{材料及び方法}

I 。患者検体を用いた検討

1. polyagglutination の分類は，表 2 に示すよ うに各種レクチン (Gamma 社製及び自家製)を使 用し, 凝集の有無で行った。

2. 血清中の抗 $\mathrm{T}$, 抗 $\mathrm{Tk}$ 抗体の有無について は, 正常赤血球を処理した $\mathrm{T}$ 化及び $\mathrm{Tk}$ 化赤血球 との凝集反応で行った。 $\mathrm{T}$ 化処理赤血球の調製 31 は, 予め乾燥 RDE (receptor destroy enzyme : 武田薬品製コレラ菌異型558株培養濾液） 1 バイア ルを生理食塩水 $20 \mathrm{ml}$ に溶解後, 溶解液と正常赤血 球沈層とを等量混ぜ， $37^{\circ} \mathrm{C}$, 15 分間反応させた。 また $\mathrm{Tk}$ 化処理赤血球は, 赤血球 1 容量と Bacter oides fragilis 株 (ATCC25285) 培養上清液 3 容量 とを混合し $37^{\circ} \mathrm{C}, 6$ 時間反応させた ${ }^{4)}$.これらの処 理赤血球の確認は, $\operatorname{Bird}^{11}$ の分類に基づきレクチ ンとの反応性で行った。

3. 患者の血清中や血液培養上清液に菌体由来 の酵素が存在するかを確認するために，次の方法 で正常赤血球と反応させた. 即ち, 患者血清や 1 倍, 10 倍, 100 倍に希釈した細菌培養上清液を等容 量の正常赤血球沈層に加えて $37^{\circ} \mathrm{C} て ゙$ 最高 29 時間ま で加温し，洗浄した.このように処理した各々の 反応時間に打ける赤血球について, Arachis hypogaea, Salvia sclarea, Salvia horminum,

表 2 Lectin reactivity of the patient's RBC

\begin{tabular}{|c|c|c|c|c|c|c|c|c|}
\hline & \multirow{2}{*}{ 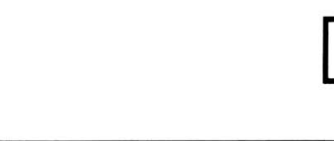 } & \multicolumn{5}{|c|}{ Polyagglutinated red cell types } & \multirow{2}{*}{\multicolumn{2}{|c|}{$\frac{\text { Patient (TT) RBC in }}{10 \% 10 \%}$}} \\
\hline & & $\mathrm{T}$ & $\mathrm{Tk}$ & 1\%: & $\mathrm{Tx}$ & $\mathrm{Tn}$ & & \\
\hline $\begin{array}{l}\mathrm{L} \\
\mathrm{e} \\
\mathrm{c} \\
\mathrm{t} \\
\mathrm{i} \\
\mathrm{n} \\
\mathrm{s}\end{array}$ & \begin{tabular}{l} 
Arachis hypogaea \\
Arachis hypogaea on papain, \\
\multicolumn{1}{c}{ Ficin treated } \\
Salvia sclarea \\
Salvia horminum \\
Glycine soja \\
Dolichos biflorus $(0, B)$ \\
BS II (Bandeiraea simplicifolia) \\
Vicia cretica
\end{tabular} & of & $\begin{array}{l}+ \\
\uparrow \\
- \\
- \\
- \\
- \\
+ \\
-\end{array}$ & 1. & $\begin{array}{l}- \\
- \\
- \\
-\end{array}$ & $\begin{array}{l}- \\
- \\
+ \\
+ \\
+ \\
+ \\
- \\
-\end{array}$ & 1. & d \\
\hline & Polybrene (1\%) & & + & . & - & $\mathrm{mf}$ & $1 \%$ & - \\
\hline
\end{tabular}

mf: mixed field 
Glycine soja, BSII などのレクチンと反応させ た. polyagglutinationの分類は $\operatorname{Bird}^{1} に$ 準じ，こ のうち Arachis hypogaea や Glycine soja レクチ ンとの赤血球凝集価をスコア

\section{II. 正常赤血球を用いた実験的検討}

1. 種々のノイラミニダーゼ (シグマ社) 濃度に おける正常赤血球の Th または $\mathrm{T}$ 化形成試験を 行った.ノイラミニダーゼを $100 \mathrm{mU}, 10 \mathrm{mU}, 1$ $\mathrm{mU}, 0.1 \mathrm{mU}$ に希釈し, 等容量の正常 $\mathrm{O}$ 型赤血球 沈層に加え $37^{\circ} \mathrm{C} て ゙ 15$ 分間から 24 時間まで種々の加 温時間で反応させた (今回の実験では, $37^{\circ} \mathrm{C}, \mathrm{pH}$ $5.0 \mathrm{~N}$-アセチルノイラミンラクトースを基質とし て 1 分間に $1 \mu$ mole の N-アセチルノイラミン酸 を遊離する酵素量をノイラミニダーゼ1Uと定義 した).これらの赤血球を洗浄後, $3 \%$ 赤血球とし, レクチン (Arachis hypogaea, Salvia sclarea, Salvia horminum, Glycine soja, BSII) との反 応性を Bird ${ }^{1)}$ 分類で確認した.このうち Arachis hypogaea と Glycine soja レクチンとの赤血 球凝集価をスコア

2.1で示したノイラミニダーゼ処理後に赤血球 から遊離したシアル酸を, Warren ${ }^{6}$ によるチオバ ルビツール酸法で定量した. 即ち, 上記 1 の反応 上清液 $0.2 \mathrm{~m} l$ に過ヨウ素酸ナトリウム $0.1 \mathrm{~m} l$ を 加え振盪し，20分間放置した。覀ヒ酸ナトリウム
溶液 $1.0 \mathrm{~m} l$ を加えて, さらに激しく振盪し褐色調 が消えた後に, チオバルビツール酸液を $3.0 \mathrm{~m} l$ 加 え, 沸騰浴中で15分間加熱した。冷却後シクロへ キサノン $4 \mathrm{~m} l$ を加え, 振盪抽出した. 遠心 $(3,000$ $\mathrm{rpm}, 5$ 分間) した上清分画を $550 \mathrm{~nm}$ の吸光度で 測定した.

3. Arachis hypogaea レクチンの各種単糖類 (Galactose, $\mathrm{N}$-acetylgalactosamine, D-mannose, Maltose, Lactose, L-fucose, N-acetyl D (+) glucosamine, D-glucose : 0.25M) による赤血球 凝集抑制試験としては, 予めレクチンと各単糖類 とを等量混合し室温15分間反応させてから, $\mathrm{T}$ 化 処理または $\mathrm{Th}$ 化処理赤血球を加えて, 凝集阻止 反応を行った。

4. Arachis hypogaea レクチンの赤血球結合 部位を確認するために, $\mathrm{T}$ 化, Th 化, 正常赤血球 をそれぞれ NP-40で可溶化し, Arachis hypogaea 固相化カラムにより精製した。これらの膜蛋白を $10 \%$ SDS-PAGE 電気泳動法で泳動した。

\section{結 果}

1. 患者の血液型は, $B, C C D e e, \operatorname{Le}(a-b-)$, MNss, $\mathrm{P}_{2}, \mathrm{kk}, \mathrm{Kp}(\mathrm{a}-\mathrm{b}-), \mathrm{Fy}(\mathrm{a}+\mathrm{b}+), \mathrm{Jk}$ $(a-b+), L u(a-b+)$, Js $(a-b+)$, Di $(a-)$ 型であった。

2. 患者赤血球における polyagglutination の

表 3 Th transformation of normal RBC on incubation with the patient's serum in vitro.

\begin{tabular}{|c|c|c|c|c|}
\hline & \multicolumn{2}{|c|}{ with the serum on day 1} & \multicolumn{2}{|c|}{ with the serum on day 2} \\
\hline Lectins & $\begin{array}{c}\text { Arachis hypogaea } \\
\text { (score) }\end{array}$ & Glycine soja & $\begin{array}{l}\text { Arachis hypogaea } \\
\text { (score) }\end{array}$ & Glycine soja \\
\hline $1 \mathrm{~h}$ & 0 & 0 & 0 & 0 \\
\hline $3 \mathrm{~h}$ & 0 & 0 & 0 & 0 \\
\hline $5 \mathrm{~h}$ & 0 & 0 & $1+(5)$ & 0 \\
\hline $7 \mathrm{~h}$ & 0 & 0 & $2+(5)$ & 0 \\
\hline $10 \mathrm{~h}$ & & & $2+\quad(13)$ & 0 \\
\hline $15 \mathrm{~h}$ & & & $4+\quad(17)$ & 0 \\
\hline $18 \mathrm{~h}$ & $1+(5)$ & 0 & & \\
\hline $20 \mathrm{~h}$ & $1+(5)$ & 0 & $4+\quad(20)$ & 0 \\
\hline $24 \mathrm{~h}$ & $1+(5)$ & 0 & $4+(25)$ & 0 \\
\hline $28 \mathrm{~h}$ & $1+(17)$ & 0 & $4+\quad(25)$ & 0 \\
\hline $29 \mathrm{~h}$ & $2+\quad(21)$ & 0 & & \\
\hline
\end{tabular}

※ Th transformed RBC has been obtained by incubation with the patient's serum for longer incubation time. 
性状について各種レクチンとの凝集反応は，入院 1 日目の赤血球については Th 活性を認めなかつ たが，2 日目の赤血球には Th 活性を認めた。一 方，血液培養液中の患者赤血球と培養上清液で処 理した正常赤血球は, 共に T 活性を示し, polyagglutinationの型に相違が見られた（表 2 ）。

3. 患者血清中には，抗 $\mathrm{T}$, 抗 $T \mathrm{k}$ 抗体の存在を
認めた。

4. 患者血清と正常赤血球との反応については, 入院 1 日目の患者血清では 18 時間加温で, 入院 2 日目の患者血清では 5 時間加温で Th 活性を認め たが，T 活性は確認できなかった（表 3 ）.

5. 患者の血液培養上清液を希釈し,正常赤血球 と反応させると, 100 倍希釈では 24 時間まで反応さ

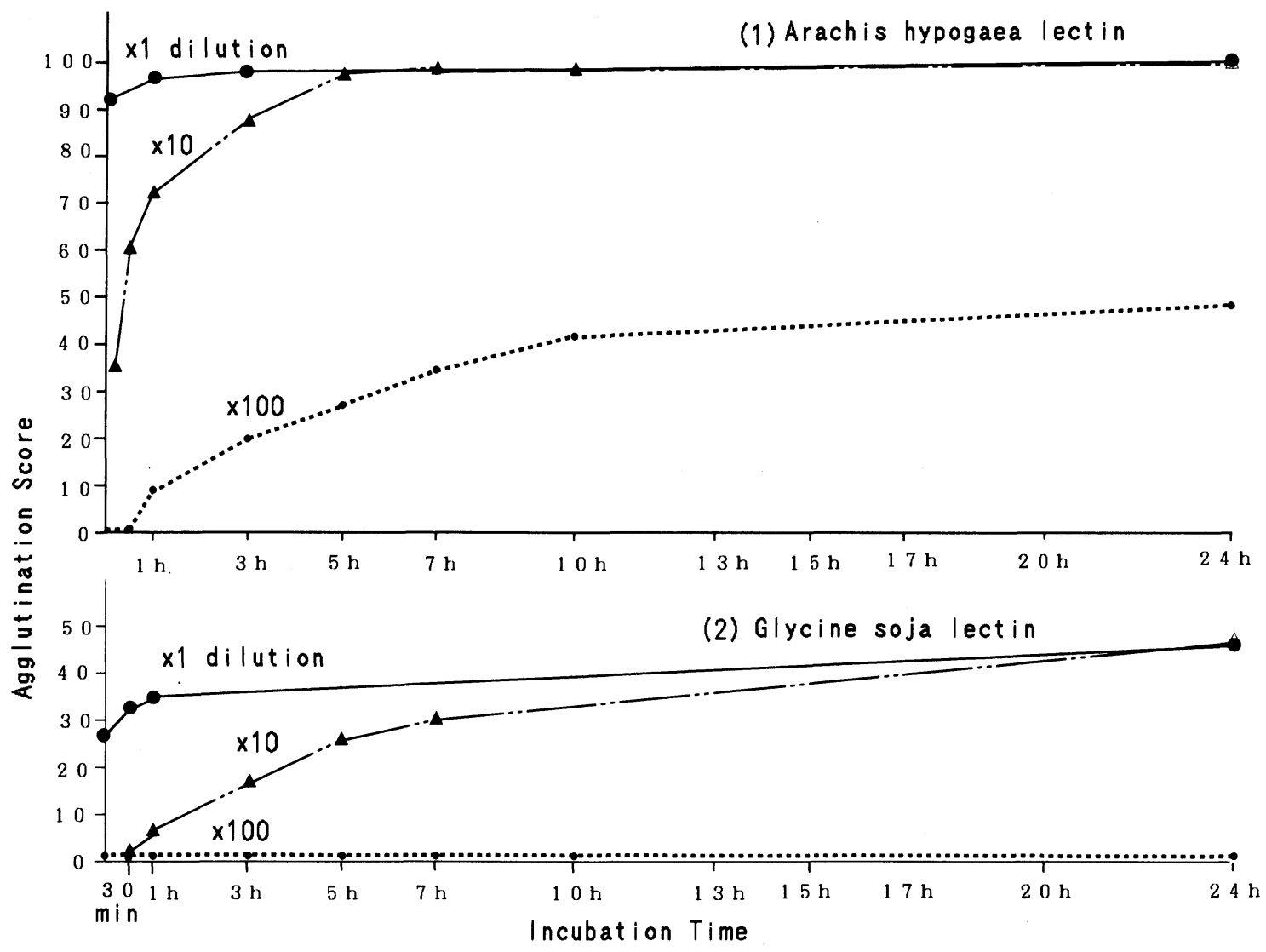

図 1 Th and T transformation of normal RBC incubated with the supernatant of the patient's blood culture: agglutination score

表 $4 \mathrm{Th}$ and $\mathrm{T}$ transformation of normal RBC incubated with the diluted supernatant of the patient's blood culture

\begin{tabular}{c|c|c|c|c|c|c|c|c|c|c|c}
\hline & \multicolumn{10}{c}{ Incubation time } \\
\hline Dilution & $30 \mathrm{~min}$ & $1 \mathrm{~h}$ & $3 \mathrm{~h}$ & $5 \mathrm{~h}$ & $7 \mathrm{~h}$ & $10 \mathrm{~h}$ & $13 \mathrm{~h}$ & $15 \mathrm{~h}$ & $17 \mathrm{~h}$ & $20 \mathrm{~h}$ & $24 \mathrm{~h}$ \\
\hline$\times 1$ & $\mathrm{~T}$ & $\mathrm{~T}$ & $\mathrm{~T}$ & $\mathrm{~T}$ & $\mathrm{~T}$ & $\mathrm{~T}$ & $\mathrm{~T}$ & $\mathrm{~T}$ & $\mathrm{~T}$ & $\mathrm{~T}$ & $\mathrm{~T}$ \\
\hline$\times 10$ & $\mathrm{Th}$ & $\mathrm{T}$ & $\mathrm{T}$ & $\mathrm{T}$ & $\mathrm{T}$ & $\mathrm{T}$ & $\mathrm{T}$ & $\mathrm{T}$ & $\mathrm{T}$ & $\mathrm{T}$ & $\mathrm{T}$ \\
\hline$\times 100$ & $\mathrm{Th}$ & $\mathrm{Th}$ & $\mathrm{Th}$ & $\mathrm{Th}$ & $\mathrm{Th}$ & $\mathrm{Th}$ & $\mathrm{Th}$ & $\mathrm{Th}$ & $\mathrm{Th}$ & $\mathrm{Th}$ & $\mathrm{Th}$ \\
\hline
\end{tabular}




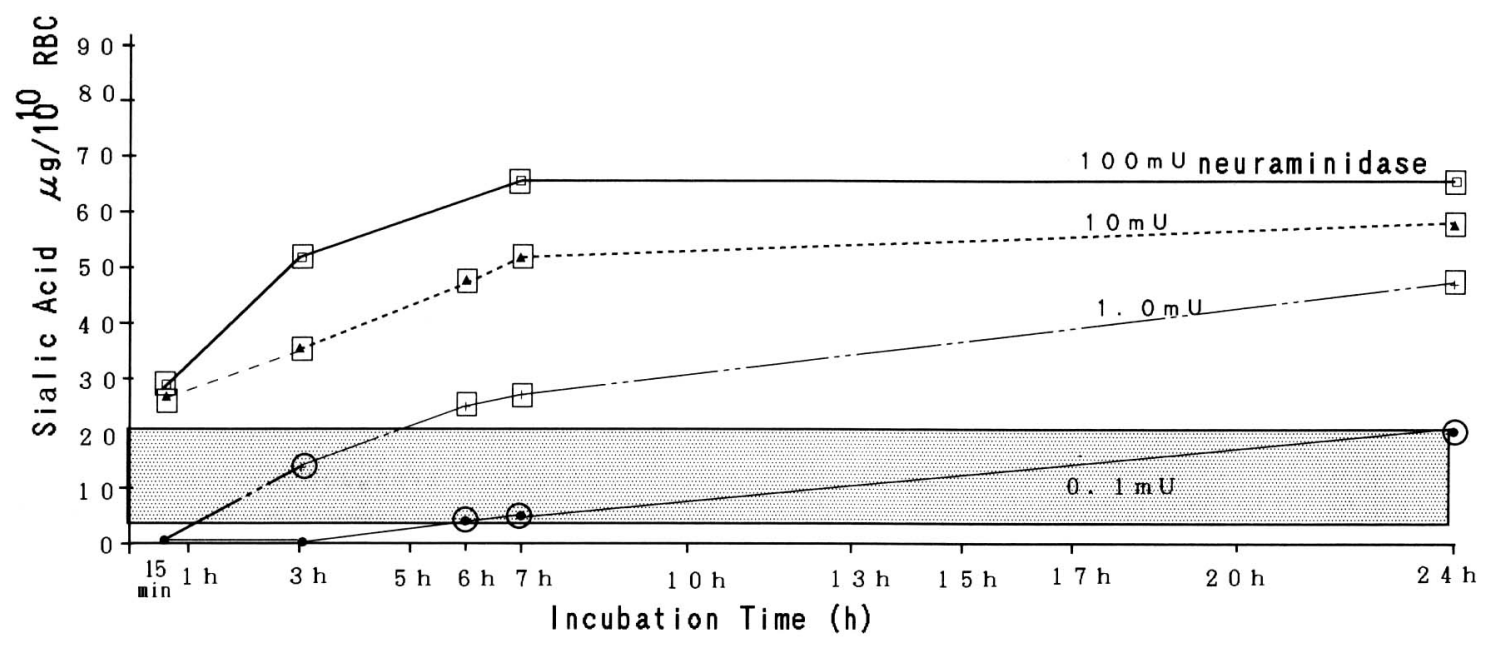

図 2 Quantification of sialic acid in the supernatant of normal RBC after neuraminidase treatment

$O$ : Th transformed RBC, $\square:$ T transformed RBC, $\quad$ : Th activated area $: 4 \sim 21 \mu \mathrm{g} / 10^{10} \mathrm{RBC}$

表 5 Agglutination of RBC by Arachis hypogaea after incubation with monosaccharides

\begin{tabular}{|c|c|c|}
\hline Monosaccharides & Th transformed RBC & $T$ transformed $R B C$ \\
\hline $0410, t<5$ & m & . \\
\hline $\mathrm{N}$-Acety lga lactosamine & $4+$ & $4+$ \\
\hline D-mannose & $4+$ & $4+$ \\
\hline Maltose & $4+$ & $4+$ \\
\hline $10108 \%$ & \% & \% \\
\hline$L$-fucose & $4+$ & $4+$ \\
\hline N-Acety $1 D(+)$ glucosamine & $4+$ & $4+$ \\
\hline D-glucose & $4+$ & $4+$ \\
\hline PBS control & $4+$ & $4+$ \\
\hline
\end{tabular}

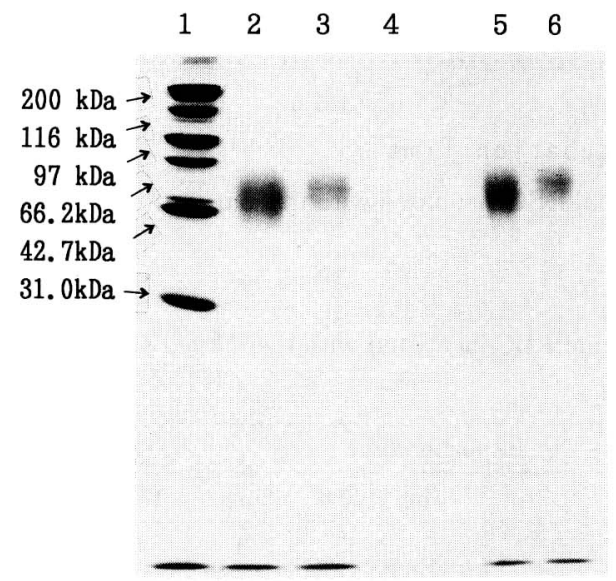

Lane 1 : marker protein.

Lane 2 : purified T , $2 \mathrm{ME}(+)$

Lane 3 : purified Th, $2 \mathrm{ME}(+)$

Lane 4 : normal RBC, $2 \mathrm{ME}(+)$

Lane 5 : purified $\mathrm{T}, 2 \mathrm{ME}(-)$

Lane 6 : purified Th, 2ME(-)

図 3 SDS-PAGE of NP-40 soluble RBC membrane protein purified by Arachis hypogaea lectin affinity column. 
せてもTh 活性が持続した。10倍希釈では30分ま での加温では Th 活性を, それ以後の加温では T 活性が誘導された（図 1 , 表 4 ).

6.ノイラミニダーゼが $0.1 \mathrm{mU}$ では 24 時間の反 応でも Th 活性が持続したが, $1.0 \mathrm{mU}$ では 3 時間 までの反応で, $10.0 \mathrm{mU}$ では 15 分間の反応で, それ ぞれ赤血球が $\mathrm{Th}$ 活性を示し，さらに反応時間を 延長すると T 活性の誘導を認めた（図 2 ).

7. Arachis hypogaea レクチンの各種単糖類 における赤血球凝集抑制試験では， $\mathrm{T}$ 化処理赤血 球, Th 化処理赤血球ともに galactose, lactose の みにより抑制が認められた（表 5 )。

8. $\mathrm{T}$ 化処理赤血球, $\mathrm{Th}$ 化処理赤血球, 正常赤 血球の Arachis hypogaea 固相化カラムにより精 製した膜蛋白は，galactoseによる凝集抑制を認 め, $10 \%$ SDS-PAGE 電気泳動を行った泳動像は, $70 \mathrm{kd} \sim 80 \mathrm{kd}$ のブロードなバンドが共にみられた (図 3 ).

\section{考察}

Th-polyagglutination は, 種々のレクチンとの 反応性により血清学的に特異性が確認されてい る ${ }^{1)}$ が，その発現機構は Judd7)の総説によると， (1) 細菌由来の酵素によりシアル酸が遊離するこ とで発現するもの，(2) 新生児や妊娠に発現が認 められ, 前者は $\mathrm{i}$ 抗原の如く胎児抗原として発現 が増加したものであり, 後者は妊娠中の代謝変化 による抗原変化で alkali-labile tetrasaccharides のシアル酸残基が欠如する不完全な合成によるも の，（3）先天性低形成貧血患者（Fanconi 貧血患 者, Diamond-Blackfan 患者等)にみられるものと されている。これらは感染症例を除き主に赤血球 膜糖類の合成系異常によって生じるものと推定さ れている。

本邦における Th-polyagglutination の報告例 は, 特発性血小板減少性紫斑病患者 ${ }^{8)}$, Myelodysplastic syndrome 患者 ${ }^{9)}$, 不応性貧血患者 ${ }^{10)}$, 溶血 性貧血患者 ${ }^{11)}$ ，急性骨髄性白血病患者 ${ }^{12)}$ な゙゙に認 められるものの, その発現理由に関しては詳細に 検討されていないが，何れも感染は否定されてい るため, 合成系の異常によるものと推察される.

しかし, 本邦に扔いては本症例のような感染症
による報告例は著者らの調べた限りでは現在のと ころ見当たらない. 本症例に認められた赤血球異 常は, 起因菌である Streptococcus pneumoniae 菌 体酵素により血清学的に Th 活性を発現したと推 定された。患者赤血球の Th 化は入院 1 日目には 認められず，入院 2 日目に認められた。その理由 として入院 1 日目の血清と正常赤血球を in vitro で18時間ふ置すると赤血球の Th 化の発現が生じ ることから，入院 1 日目ですでに血清中に酵素が 存在しており, 入院 2 日目で赤血球の $\mathrm{Th}$ 活性に 至ったものと考えられた。

Streptococcus pneumoniae 培養液に存在する酵 素としてはノイラミニダーゼが指摘されている ${ }^{13}$ ことから, 患者における Th 活性と T 活性との相 違は, 培養上清に含まれている酵素濃度と反応時 間が異なる事により生じることが示唆された。そ して両者の違いは, 酵素反応により赤血球から遊 離されるシアル酸量の違いに基づくものと考え た. 患者からの赤血球遊離シアル酸量の測定は, 第 2 病日に死亡のため直接測定は出来なかった。

シアル酸の減少と関連した汎凝集現象では, T-polyagglutinability がThより頻度も高くよ く知られている。しかも，この二つの抗原の関連 について, 生化学的に二つの異なった意見が発表 されてきた.一つは, T 活性の発現と Th のそれと の差異を脱シアル酸の程度とみなす見解である Sondag-Thull ら ${ }^{14)}$ がその代表で，「Th転換は T 化の前段階もしくは低活性状態である」との主張 をCorynebacterium aquaticum の培養上清の実 験で裏付けている。一方, Herman ら ${ }^{15)}$ にれば Fanconi 貧血患者の Th抗原構造を, ${ }^{125} \mathrm{I}$ 標識 Arachis hypogaea レクチンを用いて赤血球膜蛋 白のウエスタンブロティングを行った結果や，〔3 $\mathrm{H}$ )シアル酸と精製 sialyltransferase による T 抗 原の比較検討などから， $\mathrm{T}$ と $\mathrm{Th}$ 抗原は質的に異 なっていたと述べている。

本症例においては, 両赤血球における Arachis hypogaea レクチンの単糖類による凝集抑制は同 一であったこと，また各々の赤血球を NP-40で可 溶化した $10 \%$ SDS-PAGE の泳動像が一致してい たことから, Arachis hypogaea レクチンの反応 
部位は同一と推定された。言いかえれば, Th 発現 と T転換との違いはシアル酸遊離の量的な差に 起因すると考えられた。このことは，図 2 に示す 如く実験的に赤血球からシアル酸量が $4 \mu \mathrm{g} / 10^{10}$ $\mathrm{RBC}$ 遊離しはじめると Th 活性が始まり $21 \mu \mathrm{g} /$ $10^{10} \mathrm{RBC}$ まで持続していたが，それ以上のシアル 酸量が遊離すると $\mathrm{T}$ 活性が誘導されることに よって確認された.なおこれらの閾値は, SondagThull ら ${ }^{14)}$ の報告值 $20 \mu \mathrm{g} / 10^{10} \mathrm{RBC}$ とほほ類似し た数值であった。

以上のことから本症例のような感染症における Th 活性の発現は，T化の前段階もしくは低活性 状態にあるものと思われた。すなわちノイラミニ ダーゼにより赤血球膜上の glycophorin (GPA)の Gal-GalNAcに結合しているN-acetylneuraminic acid (NANA) の脱シアル化が Th 活 性はマイルドに起きた状態であり，大量にシアル 酸が遊離されると $\mathrm{T}$ 化が誘導されるものと推察 された。

\section{結語}

Arachis hypogaea〔Peanut extract〕レクチン によるスクリーニングから肺炎・呼吸不全で緊急 入院となった患者の赤血球に Th 活性が発現して いるのが検出された。この発現は, Streptococcus pneumoniae 感染による菌体酵素によるもので あった．種々の検討をした結果，感染症における $\mathrm{Th}$ 発現は，T 活性への前段階もしくはシアル酸 遊離の弱い状態であると考えられた。

謝辞 本症例の検討に際し, Bacteroides fragilis 株 （ATCC25285）培養上清を恵与下さいました岐皁大学嫌気 性菌実験施設渡辺教授及び本院検査部梅木一美主任技師, 山本成郎技師に深謝致します。

また，本論文の要旨は，第41回日本輸血学会総会(東京) で報告した。

\section{文 献}

1) Bird, G.W.G. Wingham, J., Beck, M.L., Pierce, S.R., Oates, G.D. and Pollock, A.: Th,a "new" form of erythrocyte polyagglutination(letter). Lancet, 1: 1215-1216, 1978.

2) Veneziano, G., Rasore-Quartino, A. and Sansone, G.: Th erythrocyte polyagglutination (letter). Lancet, 2 : 483, 1978.
3) Haynes, C.R., Dorner, I., Leonard, G., Arrowsmith, W.R. and Chaplin, H. : Persistent polyagglutinability in vivo unrelated to $\mathrm{T}$. antigen activation. Transfusion, $10: 43-51$, 1970.

4) Moulds, J.: Polyagglutination: Overview and resolution. Polyagglutination a technical workshop. p. 1-22, 1980.

5) Widmann, F.: A code for scoring agglutination reactions. Technical Manual of the AABB, 9th ed., p. 462-462, 1985.

6) Warren, L.: The thiobarbituric acid assay of sialic acids. J. Biol. Chem., 234 : 1971-1975, 1959.

7) Judd, W.J.: Review : Polyagglutination. Immunohematology, 8: 58-69, 1992.

8）大久保康人, 瀬尾たい子, 山口英夫, 塩田喜代子, 高井正治：持続性 polyagglutinability Th の 1 症例. 血液事業, $7: 13-16,1984$.

9）赤保内良和，谷村章子，仲川尚明，森田正光，川 崎君王, 小林壮光, 谷内 昭, 石井禎郎: Thpolyagglutination を伴った Myelodysplastic Syndrome. 臨床血液, $27: 54-59,1986$.

10）佐藤千秋，松島弘子，日高玩二，高崎富美子，市 川洋一，塩見善作，新井義夫，伏見隆子，前川孝 子，村田 愿，児崎宣夫：Th-polyagglutination 発現の 1 症例. 日輸血会誌, $31: 580-581,1985$.

11）深井寛治，加藤俊明，金子園明，関口定美，佐々 木正照：Polyagglutinability Th $の 1$ 症例。日輸 血会誌，31：582-583， 1985.

12）東谷孝徳, 川野洋之, 小川美津子, 吉本孝治, 南 野隆一，横山三男：Th抗原による Polyagglutination とA 抗原の発現が一過性に消失した 急性骨髄性白血病の症例。日輸血会誌 36：147, 1990.

13) Wilson, J.: A review of serologic problems caused by polyagglutinable red cells. Am. J. Med. Technol., 43 : 147-155, 1977.

14) Sondag-Thull, D., Levene, N.A., Levene, C., Manny, N., Liew, Y.W., Bird, G.W.G., Schechter, Y., François-Gérard, Ch., Huet, M. and Blanchard, D.: Characterization of a neuraminidase from Corynebacterium aquaticum responsible for Th polyagglutination. Vox Sang., 57 : 193-198, 1989.

15) Herman, J.H., Whiteheart, W., Shirey, R.S., Johnson, R.J., Kickler, T.S. and Ness, P.M.: Red cell Th activation: Biochemical studies. Br. J. Haematol., 65 : 205-209, 1987. 